\title{
ВИЯВЛЕННЯ ТА ЛІКУВАННЯ ПАЦІЄНТІВ ІЗ СІМЕЙНОЮ ГІПЕРХОЛЕСТЕРИНЕМІЄЮ
}

\begin{abstract}
Резюме. Сьогодні проблема виявлення та лікування хворих на атеросклероз, головним чином, полягає в тому, що немає всеукраїнської програми боротьби з цією хворобою, скринінгу рівня холестерину та інших фракторів ризику, відсутністні достатня інсормованість населення з питаннь данного фаху та підтримка у засобах масової інфрормації, неесрективність судинних центрів щодо зниження летальності, недостатня прихильність пацієнтів до лікування, недосягнення цільових рівнів ліпопротеїнів низької щільності та притаманний страх призначення максимальних доз статинів. В останнє десятиріччя багато даних накопичено стосовно захворювань із сімейною гіперхолестеринемією, та достоіменно відомо, що поширеність їх виявилась частішою, ніж очікувалась попередньо. Сімейна гіперхолестеринемія - це спадкове захворювання, що асоціюється 3 раннім розвитком агресивного атеросклерозу та серцево-судинних захворювань у молодому віці, що характеризується тяжким перебігом та високою летальністю. У статті викладено оглядові дані сучасного стану епідеміології, профрілактики та керування пацієнтів із сімейною гіперхолестеринемією, акцентовано увагу на раннє виявлення хворих та скринінгу сім'ї.
\end{abstract}

Ключові слова: сімейная гіперхолестеринемія; гіполіпідемічна терапія; статини.

Сімейна гіперхолестеринемія (СГХ) - це генетичне захворювання, яке характеризується високим рівнем холестерину в крові, зокрема ліпопротеїнів низької щільності (ЛПНЩ), а також раннім виникненням серцево-судинних захворювань (СС3) [1-4, 8, 10]. Залежно від успадкування цього захворювання, існує дві форми - гомозиготна сімейна гіперхолестеринемія (ГоСГХ) та гетерозиготна сімейна гіперхолестеринемія (ГСГХ) [1-3, 7, 8]. Пацієнти із СгХ зазвичай мають рівень ЛПнЩ в два рази вищий, порівняно із сібсами (брати, сестри першої лінії спорідненості), які не мають захворювання $[1,2,8$, 10]. Також відомо, що хворі із ГСГХ у віці 20-39 років мають десятикрате підвищення ризику від загальної смертності [1-3]. Пацієнти із ГоСгХ без адекватного лікування помирають до двадцятирічного віку $[3,4,8]$.

Сьогодні поширеність та стан проблеми активно вивчають у країнах Європи (ScreenPro FH), поширення ГСГХ серед європейської раси становить 1:250-500 осіб, ГоСГХ 1:100 0000-250 000 осіб. У хворих на гіперхолестеринемію СГХ буває в 5-10 \% випадків [3, 4, 7, 10].

Запідозрили наявність СГХ у пацієнта з гіперхолестеринемією можна, якщо при фрізикальному обстеженні було виявлено ксантоми сухожиль, незважаючи на його вік, ліпоїдну дугу рогівки чи горбисту ксантелазму у віці до 25 років [1-4, 6, 8-10]. Якщо було виявлено одну чи декілька ознак, то необхідно двічі визначити концентрацію ліпідів 3 проміжком часу щонайменше 10 год $[1,2,10]$. Незважаючи на те, що фрізикальні ознаки захворювання мають низьку чутливість та зустрічаються не у кожного пацієнта з СГХ, але $є$ специфрічними, тому необхідно проводити ретельну пальпацію ахіолового та сухожиль-розгиначів пальців кистей $[1,2,8,10]$. Збір сімейного анамнезу 3 деталізацією наявності ішемічної хвороби серця (IXC) або підвищеного загального холестерину (3X) $€$ пріоритетним, для цього використовують діагностичні критерії клінічного діагнозу сімейної гіперхолестеринемії згідно з критеріями Саймона Брума (Simon Broome), голандських критеріїв (The Dutch Lipid Clinic Network (DLCN)) або MEDPED (Make Early Diagnosis to Prevent Early Deaths). Далі необхідно виключити вторинні гіперхолестеринемії. Для підтвердження діагнозу використовують молекулярно-генетичне дослідження, зокрема ДНК-діагностику. Якщо пацієнтові діагностовано СГХ, то наступним етапом буде проведення каскадного скринінгу родичів хворого [1-4, 8-10].
Пацієнти із СГХ належать до осіб із високим та дуже високим ризиком серцево-судинних катастроф, тому дуже важливою $є$ рання діагностика та адекватне лікування захворювання. Терапія СГХ є пожиттєвою, тому даних пацієнтів необхідно регулярно обстежувати та спостерігати їх у динаміці. Першим та основним етапом терапії $€$ немедикаментозне лікування, а саме, дієтотерапія та модифікація стилю життя, тобто підвищення фрізичної активності, відмова від шкідливих звичок, зміна харчових звичок. Проспективні дослідження виявили, що дотримання дієти та регулярне фрізичне навантаження сприяють зниженню смертності від серцево-судинних захворювань на $40 \%[4,10]$. Медикаметозна терапія базується на застосуванні статинів, як препаратів першої лінії (інгібітори ГМК-КоА редуктази), інгібітора абсорбції холестерину (езетиміб), похідних фріброївої кислоти (фібрати), нікотинової кислоти, секвестрантів жовчних кислот (іонообмінні смоли), омега-3-поліненасичених жирних кислот та пребіотиків [1-4, 10].

Сімейну гіперхолестеринемію діагностують нечасто, та здебільшого пацієнти не знають про існування загрози раннього інфраркту міокарда (IM) чи гострого порушення мозкового кровообігу (ГПМК), тому важливо ретельно вивчати усі випадки ранніх IXC, IM чи ГПМК. На даний час існує алгоритм пошуку пацієнтів із підозрою на СГХ, що складається з декількох поступових етапів діагностики та ведення таких пацієнтів (рис. 1).

Діагностика Сімейна гіперхолестеринемія $€$ моногенним захворюванням ("хвороба одного гена"), найчастіше це пов'язано з мутацією гена рецептора лПнщ (LDLR, 19p 13.2), апобілка В (2p 24-p23), пропротеїн конвертази субтилізин-кесин 9 (PCSK9, 1p 32.3), білка адаптера 1 рецептора лПНЩ (LDLRAP1, 1p 36 - p35) $[1,2,5,7,9]$.

Захворювання на СГ підозрюють, якщо концентрація загального холестерину перевищує 7,5 моль/л або лПнщ $\geq 4,9$ моль/л у дорослих $\geq 16$ років та рівень $3 X-6,5$ моль/л або ЛПнЩ $\geq 4,1$ моль/л у дітей та підлітків; наявність раннього розвитку IXC у сімейному анамнезі (до 60 років у родичів першої лінії або до 50 років у родичів другої лінії) та за наявності сухожильних ксантом. Для клінічного встановлення діагнозу СГХ останнім часом більш поширено використовують критерії Саймона Брума (Simon Broome), голандських критеріїв (табл. 1, 2). При виникненні підозри на СГХ необхідно двічі визначити концентрацію ліпідів у 
1 етап. Пошук пацієнтів із підозрою на сімейну гіпсрхолсстеринемію:

- Виразна гіперхолестеринемія;

- Ранній анамнез захворювання, зумовлений атеросклерозом (до 55 років у чоловіків та до 60 років у жінок);

- Ксантоматоз;

• Виключення вторинних гіперхолестеринемій

2 етап. Встановлення діагнозу сімейної гіперхолестеринемії:

- Виявлення пробанда, особи у якої вперше в сім'ї було виставлено діагноз СгХ*;

- Каскадний скринінг родичів пробанда;

- Оцінка додаткових серцево-судинних сракторів ризику та наявності атеросклерозу

3 етап. Визначення тактики лікування та підбір терапії

4 етап. Динамічне спостереження

Примітка. *- СГX - сімейна гіперхолестеринемія.

Рис. 1. Алгоритм виявлення та ведення хворих із сімейною гіперхолестеринемією.

Таблиця 1. Діагностичні критерії клінічного діагнозу сімейної гіперхолестеринемії згідно з критеріями Саймона Брума (Simon Broome)

\begin{tabular}{|c|c|c|}
\hline Критерій & Показник & Оцінка \\
\hline Генетичне дослідження & Мутація ДНК, пов'язана з сімейною гіперхолестеринемією & Категорія A \\
\hline \multirow[t]{2}{*}{ Ліпідна панель } & У дорослих: 3Х >7,5 ммоль/л або ХС лПнЩ >4,9 ммоль/л & Категорія В \\
\hline & У педіатричних хворих: 3Х >6,7 ммоль/л або ХС лПНЩ >4,0 ммоль/л & Категорія В \\
\hline $\begin{array}{l}\text { Дані об'єктивного } \\
\text { спостереження }\end{array}$ & $\begin{array}{l}\text { Сухожильні ксантоми у пацієнта, або хоча б у одного родича першої } \\
\text { або другої лінії спорідненості }\end{array}$ & Категорія C \\
\hline \multirow[t]{2}{*}{ Спадковий анамнез } & $\begin{array}{l}\text { Інсраркт міокарда у віці <60 років у родичів першої лінії або у віці <50 } \\
\text { років у родичів другої лінії спорідненості }\end{array}$ & Категорія E \\
\hline & $\begin{array}{l}\text { Рівень } 3 X>7,5 \text { ммоль/л хоча б у одного родича першої або другої лінії } \\
\text { спорідненості }\end{array}$ & Категорія E \\
\hline \multirow[t]{2}{*}{ Достовірна СГХ } & \multicolumn{2}{|l|}{ Категорія A } \\
\hline & \multicolumn{2}{|l|}{ Категорія B + Категорія C } \\
\hline \multirow[t]{2}{*}{ Вірогідна СгХ } & \multicolumn{2}{|l|}{ Категорія B + Категорія D } \\
\hline & \multicolumn{2}{|l|}{ Категорія B + Категорія E } \\
\hline
\end{tabular}

Примітка. IXC - ішемічна хвороба серця, лПнщ - ліпопротеїни низької щільності, СгХ - сімейна гіперхолестеринемія.

плазмі (в т.ч. холестерину ліпопротеїнів низької щільності (лПНЩ), бажано з мінімальним проміжком - 10 год, зібрати сімейний анамнез щодо IXC або гіперхолестеринемії, наступним етапом необхідно виключити вторинні гіперхолестеринемії (табл. 3) [1-4, 8, 10].

При підозрі на СГХ у хворого в молодому віці з гіперхолестеринемією необхідно провести цільовий скринінг - вивчити анамнез на наявність захворювань, що можуть бути зумовлені атеросклерозом, можливий диспансерний нагляд у кардіолога чи невропатолога, судинного хірурга.

Якщо в сім'ї в одного з батьків наявні фенотипові прояви СГX, а саме, ксантоматоз чи ранній розвиток IXC, необхідно якомога раніше обстежити всю родину, щоб виключити СГХ [1, 2, 6, 7, 9].

Важливо підкреслити, що відсутність вищевказанних ознак не виключає діагнозу СГХ, який можливо встановити без залучення молекулярно-генетичного аналізу зацікавлених генів (LDLR, APOB, PCSK9, LDLRAP1), але при наявності результатів генетичного тестування істотно полегшується робота, спрямована на проведення каскад- ного скринінгу, який може бути корисним для планування сім'ї, а також підвищує прихільність пацієнта до лікування. Негативний генетичний тест на одну з мутацій не виключає діагнозу СГХ, тому що приблизно у 20 \% мутацій у хворих даного профрілю виявити не вдається $[1,4,8]$.

При наявності в сім'ї одного хворого 3 діагнозом достовірної СГХ чи ймовірної СГХ, необхідно провести каскадний скринінг усіх родичів, починаючи з першої лінії, дальше другої та третьої. Метою каскадного скринігу $€$ виявлення захворювання на доклінічному етапі, а це, у свою чергу, дозволяє своєчасно провести комплекс превентивних заходів для попередження розвитку серцевосудинних катастрофр $[1-3,8]$.

Після проведення каскадного скринінгу необхідно провести генетичний та френотиповий скринінг родичів пробанда. Якщо за результатами генетичного тестування родичів було отримано негативний результат або немає можливості для проведення такого роду дослідження, можна використати фенотиповий скринінг. Діагностичні критерії клінічного діагнозу сімейної 
Таблиця 2. Діагностичні критерії клінічного діагнозу сімейної гіперхолестеринемії згідно з критеріями Dutch Lipid Clinic Network

\begin{tabular}{|c|c|}
\hline Група 1. Сімейний анамнез & Бал \\
\hline Родичі першої лінії із встановленим фрактом IXC або & 1 \\
\hline $\begin{array}{l}\text { Родичі першої лінії із встановленим фрактом підвищеного рівня лпНщ >95 перцентиля для } \\
\text { відповідного віку, статі у певній країні }\end{array}$ & 1 \\
\hline Родичі першої лінії із сухожильними ксантомами та/або з сенильною дугою рогівкою або & 2 \\
\hline $\begin{array}{l}\text { Діти <18 років із рівнем ЛПнЩ >95 перцентиля, стандартизованого згідно зі статтю та } \\
\text { віком, відповідно до країни }\end{array}$ & 2 \\
\hline Група 2. Клінічний анамнез & Бал \\
\hline Пацієнт має ранній початок розвитку IXC & 2 \\
\hline Пацієнт має ранній початок розвитку церебрального або переферійного атеросклерозу & 1 \\
\hline Група 3. Об'єктивне обстеження & Бал \\
\hline Сухожильні ксантоми & 6 \\
\hline Сенильна дуга рогівки, у віці <45 років & 4 \\
\hline Група 4. Біохімічні результати показників лпнщ & Бал \\
\hline >325 мг/дл (8,5 ммоль/л) & 8 \\
\hline 251-325 мг/дл (6,5-8,4 ммоль/л) & 5 \\
\hline 191-250 мг/дл (5,0-6,4 ммоль/л) & 3 \\
\hline 155-190 мг/дл (4,0-4,9 ммоль/л) & 1 \\
\hline Група 5. Молекулярна діагностика (аналіз ДНК) & Бал \\
\hline Мутація гена Лпнщ (LDLR, APOB, PCSK9) & 8 \\
\hline Певний діагноз СГХ & $>8$ \\
\hline Ймовірна СГХ & $6-8$ \\
\hline Можлива СГХ & $3-5$ \\
\hline Малоймовірна & $1-3$ \\
\hline
\end{tabular}

Примітка. IXC - ішемічна хвороба серця, лПНЩ - ліпопротеїни низької щільності, СгХ - сімейна гіперхолестеринемія.

Таблиця 3. Вторинні причинні гіперліпідемії, що найчастіше бувають у клінічній практиці

\begin{tabular}{|c|c|c|}
\hline Причина & Підвищення рівня ХС лПНЩ & Підвищення рівня ТГ \\
\hline Дієта & $\begin{array}{l}\text { Насичені або ненасичені жири, зайва маса } \\
\text { тіла, анорексія }\end{array}$ & $\begin{array}{l}\text { Зайва маса тіла, дієта з дуже низьким вмістом } \\
\text { жирів, надлишок рафрінованих вуглеводів, надмірне } \\
\text { споживання алкоголю }\end{array}$ \\
\hline $\begin{array}{l}\text { Медикаментозні } \\
\text { препарати }\end{array}$ & $\begin{array}{l}\text { Діуретики, циклоспорини, глюкокортикоїди, } \\
\text { аміодарон, імунодепресанти, високоактивна } \\
\text { ретровірусна терапія у ВІЛ-інфрікованих хворих }\end{array}$ & $\begin{array}{l}\text { Пероральні естрогени, глюкокортикоїди, } \\
\text { секвестранти жовчних кислот, інгібітори протеаз. } \\
\text { Анаболічні стероїди, препарати ретиноєвої кислоти, } \\
\text { сиролімус, ралоксифен, тамоксифен, ББ (окрім } \\
\text { карведилолу), тіазиди }\end{array}$ \\
\hline Захворювання & Холестаз, нефрротичний синдром & Нефрротичний синдром, ХНН, ліподисторофрія \\
\hline $\begin{array}{l}\text { Порушення та зміни } \\
\text { обміну речовин }\end{array}$ & Гіпотиреоз, ожиріння, вагітність & $\begin{array}{l}\text { ЦД (недостатньо контрольований), гіпотиреоз, } \\
\text { ожиріння, вагітність, синдром Кушинга }\end{array}$ \\
\hline
\end{tabular}

Примітка. ББ - бета-блокатори, ВІЛ - вірус імунодефіциту лідини, ХНН - хронічна ниркова недостатність, ЦД - цукровий діабет.

гіперхолестеринемії Саймона Брума (Simon Broome) продемонстрували високу чутливість (93 \%) та специфічність (82 \%) у дослідженнях російської популяції (рис. 2) [3].

Лікування При виявленні СГХ необхідно проінформувати пацієнта про наявність високого або дуже високого ризику виникнення серцево-судинних та цереброваскулярних катастрофр, що пов'язано з розвитком атеросклерозу. Шкалу SCORE для визначення ризику серцево-судинних катастроф у пацієнтів із СГХ використовувати недоцільно. Для лікування хворих із СГХ тра- диційно спочатку проводять корекцію фракторів ризику та модифрікування повсякденного життя. Корекцію фракторів ризику проводять шляхом відмови від тютюнокуріння, також контроль за артеріальним тиском, індексом маси тіла, обмеження споживання продуктів, збагачених холестерином, не більше 200 мг/день холестерину та підвищення вживання продуктів, що містять рослинні стероли і станоли, що за даними досліджень можуть знизити концентрацію ЛПНЩ у людей із ГСГХ [2-4, 8, 10]. Усім пацієнтам із СГХ призначають дієтотерапію, беручи до 


\begin{tabular}{|c|c|c|c|c|c|}
\hline \multicolumn{1}{|l|}{ Вік } \\
\hline $0-14$ & $15-24$ & $25-34$ & $35-44$ & $45-54$ & $>55$ \\
\hline 5,3 & 5,3 & 5,3 & 5,3 & 5,3 & 5,3 \\
\hline 5,2 & 5,2 & 5,2 & 5,2 & 5,2 & 5,2 \\
\hline 5,1 & 5,1 & 5,1 & 5,1 & 5,1 & 5,1 \\
\hline 5,0 & 5,0 & 5,0 & 5,0 & 5,0 & 5,0 \\
\hline 4,9 & 4,9 & 4,9 & 4,9 & 4,9 & 4,9 \\
\hline 4,8 & 4,8 & 4,8 & 4,8 & 4,8 & 4,8 \\
\hline 4,7 & 4,7 & 4,7 & 4,7 & 4,7 & 4,7 \\
\hline 4,6 & 4,6 & 4,6 & 4,6 & 4,6 & 4,6 \\
\hline 4,5 & 4,5 & 4,5 & 4,5 & 4,5 & 4,5 \\
\hline 4,4 & 4,4 & 4,4 & 4,4 & 4,4 & 4,4 \\
\hline 4,3 & 4,3 & 4,3 & 4,3 & 4,3 & 4,3 \\
\hline 4,2 & 4,2 & 4,2 & 4,2 & 4,2 & 4,2 \\
\hline 4,1 & 4,1 & 4,1 & 4,1 & 4,1 & 4,1 \\
\hline 4,0 & 4,0 & 4,0 & 4,0 & 4,0 & 4,0 \\
\hline 3,9 & 3,9 & 3,9 & 3,9 & 3,9 & 3,9 \\
\hline 3,8 & 3,8 & 3,8 & 3,8 & 3,8 & 3,8 \\
\hline 3,7 & 3,7 & 3,7 & 3,7 & 3,7 & 3,7 \\
\hline 3,6 & 3,6 & 3,6 & 3,6 & 3,6 & 3,6 \\
\hline 3,5 & 3,5 & 3,5 & 3,5 & 3,5 & 3,5 \\
\hline 3,4 & 3,4 & 3,4 & 3,4 & 3,4 & 3,4 \\
\hline 3,3 & 3,3 & 3,3 & 3,3 & 3,3 & 3,3 \\
\hline 3,2 & 3,2 & 3,2 & 3,2 & 3,2 & 3,2 \\
\hline
\end{tabular}

Жінки

Вірогідний діагноз СГХ

СГХ відсутня

\begin{tabular}{|c|c|c|c|c|c|}
\hline $0-14$ & $15-24$ & $25-34$ & $35-44$ & $45-54$ & $>55$ \\
\hline 5,3 & 5,3 & 5,3 & 5,3 & 5,3 & 5,3 \\
\hline 5,2 & 5,2 & 5,2 & 5,2 & 5,2 & 5,2 \\
\hline 5,0 & 5,1 & 5,1 & 5,1 & 5,1 & 5,1 \\
\hline 4,9 & 4,9 & 4,9 & 4,9 & 5,0 & 5,0 \\
\hline 4,8 & 4,8 & 4,8 & 4,8 & 4,8 & 4,8 \\
\hline 4,7 & 4,7 & 4,7 & 4,7 & 4,7 & 4,7 \\
\hline 4,6 & 4,6 & 4,6 & 4,6 & 4,6 & 4,6 \\
\hline 4,5 & 4,5 & 4,5 & 4,5 & 4,5 & 4,5 \\
\hline 4,4 & 4,4 & 4,4 & 4,4 & 4,4 & 4,4 \\
\hline 4,3 & 4,3 & 4,3 & 4,3 & 4,3 & 4,3 \\
\hline 4,2 & 4,2 & 4,2 & 4,2 & 4,2 & 4,2 \\
\hline 4,1 & 4,1 & 4,1 & 4,1 & 4,1 & 4,1 \\
\hline 4,0 & 4,0 & 4,0 & 4,0 & 4,0 & 4,0 \\
\hline 3,9 & 3,9 & 3,9 & 3,9 & 3,9 & 3,9 \\
\hline 3,8 & 3,8 & 3,8 & 3,8 & 3,8 & 3,8 \\
\hline 3,7 & 3,7 & 3,7 & 3,7 & 3,7 & 3,7 \\
\hline 3,6 & 3,6 & 3,6 & 3,6 & 3,6 & 3,6 \\
\hline 3,5 & 3,5 & 3,5 & 3,5 & 3,5 & 3,5 \\
\hline 3,4 & 3,4 & 3,4 & 3,4 & 3,4 & 3,4 \\
\hline 3,3 & 3,3 & 3,3 & 3,3 & 3,3 & 3,3 \\
\hline 3,2 & 3,2 & 3,2 & 3,2 & 3,2 & 3,2 \\
\hline 3,1 & 3,1 & 3,1 & 3,1 & 3,1 & 3,1 \\
\hline 3,0 & 3,0 & 3,0 & 3,0 & 3,0 & 3,0 \\
\hline
\end{tabular}

Чоловіки

Можливий діагноз СГХ

Рис. 2. Біохімічні критерії сімейної гіперхолестеринемії для родичів залежно від віку та рівня ліпопротеїнів низької щільності (ICE National institute for clinical excellence 2008).

уваги місцеві харчові звички, але перевагу надають більш корисній їжі, рекомендовано знизити споживати харчову сіль до 5 мг/день, обмежити вживання алкогольних напоїв до 10-20 г/день - для жінок та 20-30 г/день - для чоловіків; у пацієнтів із гіпертригліцеридемією алкоголь необхідно виключити, а також надати рекомендації щодо дотримання індивідуальних дозованих фрізичних навантажень під контролем частоти серцевих скорочень та артеріального тиску [1-4, 8-10]. Наступним кроком у лікуванні пацієнтів із СГХ є статинотерапія. 3 огляду на постійний прийом статинів та частий розвиток побічних реакцій, доцільним $є$ застосування фрармакогенетичного тестування та визначення поліморфізму гена SLCO1B1 для стратифікації ризиків розвитку небажаних реакцій та персоніфікації максимальної дози статинів до початку лікування. На початку лікування застосовують максимальні дози: "Розувастатин" - 40 мг/добу та "Аторвастатит" - 80 мг/добу. Метою медикаментозного лікування $€$ досягення цільових рівнів ЛПНЩ <2,6 моль/л та <1,8 моль/л при наявності IXC, цукрового діабету, виразного атеросклерозу брахіоцефальних або периферичних артерій. Якщо неможливо досягти цільових рівнів ЛПНЩ, необхідно знизити показник на 50 \% від початкового рівня [1, $2,7,8]$.

Клінічний перебіг ГосГХ більш тяжкий, тому золотим стандартом лікування $€$ застосування програмного афре- 
резу лПнщ - екстракорпоральне видалення лПнщ із плазми перисрерійної крові.

За показаннями терапію можна доповнити застосуванням еволокумабу - 420 мг 1 раз на місяць, підшкірно; якщо пацієнт перебуває на асререзі евалокумаб застосовують 1 раз на два тижні, згідно з графріком афререзу [5, 10].

На початку статинотерапії необхідне всебічне спостереження за пацієнтом та моніторинг для оцінки ефективності та переносимості лікування, а саме, визначення фонкціональних печінкових тестів протягом 3-х місяців після початку лікування і через 12 місяців (якщо вони мають відхилення від норми) у разі розвитку м'язових симптомів, зокрема біль або слабкість, необхідною є перевірка КФК.

Якщо рівень печінкових трансаміназ перевищує рівень базальних показників більше 3 разів, необхідно або припинити прийом статину та перевірити печінкові проби протягом 4-6 тижнів, або зменшити дозу статину та перевірити рівень печінкових трансаміназ протягом 4-6 тижнів і розглянути можливість призначення жовчних кислот (смол), нікотинової кислоти або фрібратів [1, 2, 7, 8, 10].

\section{СПИСОК ЛІТЕРАТУРИ}

1. Семейная гиперхолестеринемия: обследование, диагностика и лечение взрослых и детей. Клиническое руководство группы экспертов по семейной гиперхолестеринемии Национальной липидной ассоциации США // Афферентная и фризикохимическая медицина. - 2012. - № 1. - С. 3-9.

2. Современные рекомендации Европейского общества кардиологов и Европейского общества по борьбе с атеросклерозом по лечению дислипидемий // Український терапевтичний журнал. - 2013. - № 2. - С. 12-23.

3. Российские рекомендации по диагностике и лечению семейной гиперхолестеринемии / М. В. Ежов, И. В. Сергиенко, Т. А. Рыжкова // Атеросклероз и дислипидемии. - 2016. - № 4 (25). - C. 21-29.

4. Integrated guidance on the care of familial hypercholesterolemia from the International FH Foundation // International Journal of Cardiology. - 2014. - Vol. 171. - P. 309-325.

5. Nathan D. Advanced in dyslipidemia management for prevention of atherosclerosis: PCSK9 monoclonal antibody therapy and beyond / D. Nathan Wong, D. Paul Rosenblit, S. Robert Greenfield // Cardiovas. Diagn. Ther. - 2017. - Vol. 7 (Suppl. 1). - P. 11-20.
6. Half of century tales of familial hypercholesterolemia $(\mathrm{FH})$ in Japan / Division of Clinical Lipidology, Department of Cardiology, Kanazawa University // J. Atheroscler. Thromb. - Vol. 24. - 2017. - P. 189-207.

7. Sharifi M. / Genetic architecture of Familial Hypercholesterolemia / M. Sharifi, M. Futema, S. E. Humphries // Curr. Cardiol. Rep. Vol. 19. - 2017. - P. 19-44.

8. Diagnostic and treatment of familial hypercholesterolemia / G. K. Hovingh, M. H. Davidson, J. J. P. Kastelein, A. M. O'Connor // Europen Heart J. - 2013. - Vol. 34, Issue 13. - P. 962-971.

9. Clinical, Anthropometric and biochemical characteristics of patients with or without genetically confirmed familial hypercholesterolemia / A. Lorenzo, J. D. L. D Silva, C. E. James [et al.] / Arq. Bras. Cardiol. - 2018. - Vol. 110. - 2018. - P. 119-123.

10. Clinical management of heterozygous familial hypercholesterolemia in a Polish outpatient metabolic clinic: a retrospective observational study / L. Klosiewicz-Latoszek, B. Cybulska, J. Bialobreska-Paluszkiewicz [et al.] // Arch. Med. Sci. 2018. - Vol. 14 (5). - 2018. - P. 962-970.

Отримано 16.08 .18

Електронна адреса для листування: iegormaznichenko@gmail.com

(๐). O. Yakimenko, Ye. O. Maznichenko Odesa National Medical University

\section{DETECTION AND TREATMENT OF PATIENTS WITH FAMILIAL HYPERCHOLESTEROLEMIA}

Summary. At present, the problem of the detection and treatment of patients with atherosclerosis is mainly due to the fact that there is no nationwide program to combat atherosclerosis, cholesterol screening and other risk factors, there is not enough adequate awareness of the population on the issues of this specialty and media support, ineffective vascular centers concerning reduction of lethality, insufficient patient adherence to the treatment, failure to reach the target levels of low density lipoprotein and inherent fear of administration the maximal doses of statins. Over the last decade, many data have been accumulated on familial hypercholesterolemia, and it is known that the prevalence of the disease has been more frequent than previously anticipated. Familial hypercholesterolemia is a hereditary disease that is associated with the early development of aggressive atherosclerosis and cardiovascular disease at young age, and is characterized by a severe course with high mortality. The paper provides an overview of the current state of epidemiology, prevention and management of patients with familial hypercholesterolemia, emphasizes the early detection of patients and screening of the family.

Key words: familial hypercholesterolemia; hypolipidemic therapy, statins.

(СЕ. А. Якименко, Е. А. Мазниченко

Одесский национальный медицинский университет ВЫЯВЛЕНИЕ И ЛЕЧЕНИЕ ПАЦИЕНТОВ ИЗ СЕМЕЙНОЙ ГИПЕРХОЛЕСТЕРИНЕМИЕЙ

Резюме. На сегодняшний день проблема выявления и лечения больных атеросклерозом, главным образом, заключается в том, что нет всеукраинской программы борьбы с атеросклерозом, скрининга уровня холестерина и других фракторов риска, отсутствие достаточной информированности населения по данным вопросам и поддержки в средствах массовой информации 
- и неэффективность сосудистых центров по снижению летальности, недостаточная приверженность пациентов к лечению, не достижение целевых уровней липопротеинов низкой плотности и привычный страх назначения максимальных доз статинов. В последние десятилетие много данных накоплено относительно заболевания семейной гиперхолестеринемиеи, известно, что распространенность заболевания оказалась более частой, чем ранее ожидалась. Семейная гиперхолестеринемия - это наследственное заболевание, ассоциирующееся с ранним развитием агрессивного атеросклероза и сердечно-сосудистых заболеваний в молодом возрасте, характеризуется тяжелым течением и высокой летальностью. В статье изложены обзорные данные современного состояния эпидемиологии, профилактики и менеджмента пациентов с семейной гиперхолестеринемией, акцентировано внимание на раннее выявление больных и скрининга семьи.

Ключевые слова: семейная гиперхолестеринемия; гиполипидемическая терапия; статины. 